\title{
MEF2A wt Allele
}

National Cancer Institute

\section{Source}

National Cancer Institute. MEF2A wt Allele. NCI Thesaurus. Code C92155.

Human MEF2A wild-type allele is located in the vicinity of $15 q 26$ and is approximately 150 $\mathrm{kb}$ in length. This allele, which encodes myocyte-specific enhancer factor 2A protein, is involved in both myogenesis and growth factor or stress-stimulated transcriptional regulation. 